\title{
Heavy metal and metalloid accumulation in wild brown trout (Salmo trutta L., 1758 complex, Osteichthyes: Salmonidae) from a mountain stream in Sardinia by ICP-OES
}

\author{
Angioni Alberto $(\mathbb{D} \cdot$ Corrias Francesco $\cdot$ Alessandro Atzei $\cdot$ \\ Sabatini Andrea (1) Palmas Francesco (1) - Lai Carla $\cdot$ Russo Mariateresa
}

Received: 23 November 2020 / Accepted: 7 June 2021 / Published online: 26 June 2021

(C) The Author(s) 2021

\begin{abstract}
This paper reports heavy metal and metalloid accumulation in wild brown trout (Salmo trutta L., 1758 complex) raised in freshwater and uncontaminated Sardinia system (Italy). Metals are widespread pollutants of aquatic systems, and their contamination can originate from anthropogenic activities such as industrial waste, agricultural and domestic environments, and geochemical release. Fish has a relevant position within the human diet; moreover, fishes can accumulate metals, making them a valuable tool as biomarkers for risk assessment studies. The concentration of 22 metals and metalloids after chemical digestion was assessed by inductively coupled plasma-optic
\end{abstract}

Summary Brown trout represent an attractive speciesfor the evaluation of heavy metal and metalloid contamination. The THQ valuescalculated for the single metals showed no adverse effects when the gut was discarded from the fish beforeeating.

\footnotetext{
A. Alberto $(\bowtie) \cdot$ C. Francesco $\cdot$ A. Atzei $\cdot$ L. Carla

Department of Life and Environmental Science,

Chemical Food Analysis Laboratory, University

of Cagliari, University Campus of Monserrato S.S. 554,

Sestu. S.P. Monserrato, Bivio Monserrato Sestu Km 0,

700 Monserrato, Italy

e-mail: aangioni@unica.it

C. Francesco

e-mail: francesco.corrias@unica.it
A. Atzei
e-mail: alessandro.atzei@unica.it
L. Carla
e-mail: carla.lai82@googlemail.com

emission spectroscopy (ICP-OES) in both the guts and the edible part (EP, muscle + skin) of brown trout. The results, expressed as $\mu \mathrm{g} \mathrm{g}^{-1}$, showed different levels of accumulation in the EP and guts, following the series $\mathrm{Cu}>\mathrm{Zn}>\mathrm{Ba}>\mathrm{Al}>\mathrm{Sr}>\mathrm{Fe}>\mathrm{Pb}$ and $\mathrm{Fe}>\mathrm{Al}>\mathrm{Hg}>$ As $>\mathrm{Mn}>\mathrm{Cu}>\mathrm{Ba}>\mathrm{B}>\mathrm{Zn}>\mathrm{Pb}$, respectively. PCA analysis showed a fairly good correlation between the total lipid and SAFA content and $\mathrm{Cd}, \mathrm{Hg}$, and $\mathrm{Pb}$ accumulation in the gut. Non-carcinogenic risk assessment, expressed as THQ (target hazard quotient), showed values far below 1 for all metals in muscles, while high As and $\mathrm{Hg}$ contamination of the gut draws attention to possible health risks which should be discarded from the fish before consumption. TR (target cancer risk) values showed alarmingly high values for $\mathrm{As}$ and $\mathrm{Cd}$ when the fish were consumed entirely (gut $+\mathrm{EP}$ ), while $\mathrm{Pb}$ levels were far below the safety levels.

\footnotetext{
S. Andrea $\cdot$ P. Francesco

Department of Life and Environmental Science,

Sustainable Development and Management of Marine and Freshwater Resources, University of Cagliari, via

Fiorelli 1, 09126 Cagliari, Italy

e-mail: asabati@unica.it

P. Francesco

e-mail: fpalmas@unica.it

R. Mariateresa

Department of Agricultural Science, Mediterranean

University of Reggio Calabria, Località Feo di Vito, 89122 Reggio Calabria (RC), Italy

e-mail: mariateresa.russo@unirc.it
} 
Keywords Geochemical pollution - Salmo trutta . Target hazard quotient . Target cancer risk

\section{Introduction}

Heavy metals are naturally occurring element present in trace amounts that can contaminate animals, vegetables, and fish along the food chain and are a problem for human safety (Masindi \& Muedi, 2018). Maximum levels of heavy metals have been set in foodstuffs (EC 1881/2006, 2020; EC $629 / 2008,2020$ ), together with the official method of analysis (EURL, 2012).

Fish and other water organisms can be affected by water pollution, mainly accumulating chemical substances that remain in the water columns for a relatively long time (Gündoğdu \& Erdem, 2008). Metals can positively affect organisms; however, they can also affect fish's biochemical functions in terms of growth, reproduction, and wellbeing (Wang et al., 2017a, b).

The concentration of heavy metals in fish has been extensively studied over the past several decades. Researchers have shown that the degree of metal accumulation in fish is dependent on the metal type, fish species, age, sex, geographical distribution, and tissue (Petrovic et al., 2013; Ptashynski et al., 2002).

Fish and seafood products are primary components of the human diet due to their nutrients, showing high levels of healthy polyunsaturated fatty acids of the $\omega 3$ series (EPA and DHA), which are associated with a reduced heart disease risk (Corrias et al., 2020a; Psota et al., 2006; Wang et al., 2017a, b), micronutrients, and high-quality protein (Garcia-Esquinas et al., 2019; Harris et al., 2008; Lee et al., 2008; Mohanty et al., 2019).

In Italy, an average fish consumption of $30.9 \pm 0.6 \mathrm{~kg} /$ per capita was calculated in 2017 (Eumofa, 2020). Italy was the first producer of salmonids in the EU, and Oncorhynchus mykiss (Pastorino $\&$ Prearo, 2015) represents the first fish from aquaculture, with 35,100 tons produced in 2017. Trout farming in Sardinia is carried out by a few small family producers, for a total harvest of 1 ton per year. To date, the only small-scale fish farm (Sadali fish farm) producing trout fry was entirely devoted to the production of Mediterranean native trout for experimental reintroduction programmes (Sabatini et al., 2011, 2018).

Since the 1970s, an evident progressive reduction in native trout presence in the original areas has been observed (Cottiglia, 1968). In Sardinia, the rivers host two non-native species: rainbow trout (Oncorhynchus mykiss) and brown trout of North Atlantic origin (Salmo trutta). The introduction of brown trout carried out with stocking programmes determined a genetic admixture between native and foreign trout belonging to the Salmo trutta complex (Berrebi et al., 2019; Sabatini et al., 2006, 2011; Splendiani et al., 2019).

In Sardinia, trout populations are exposed to anthropogenic stressors such as habitat fragmentation, limited water resources, and habitat pollution. However, a limited salmonid population is currently concentrated in the central-eastern part of Sardinia, where medium-low temperatures, flow regimens, and null or very low anthropic pollution characterize these habitats (Palmas et al., 2017). In this context, trout species represent an appealing model to assess the biological impact of environmental and geochemical contamination in freshwater ecosystems (Bajc et al., 2005; Davidson et al., 2009; Gündoğdu \& Erdem, 2008; Linde et al., 1996, 2001).

This paper reports a contamination study of a profile of 22 metals and metalloids by ICP-OES of the edible part (EP) (muscle plus skin) and guts in wild samples (Salmo trutta L., 1758 complex, sensu; Bernatchez et al., 1992) collected from a mounting freshwater stream in an uncontaminated site in Sardinia. Moreover, it evaluated the non-carcinogenic (THQ) and carcinogenic (TR) human health risks associated with fish consumption. Finally, analysis of total protein, lipids, and fatty acids was carried out on fish muscles and gut for compositional studies.

\section{Materials and methods}

Study area and sample collection

Ten wild adult brown trout samples ( $>10 \mathrm{~cm} \mathrm{TL}$ ) were collected in June 2018 from a headwater tributary of Flumendosa River (Ermolinus Stream, 39 $52^{\prime} \mathrm{N}$, 
Fig. 1 Rio Ermolinus, Montarbu Forest, and anthropogenic pressure classes in Sardina, Italy
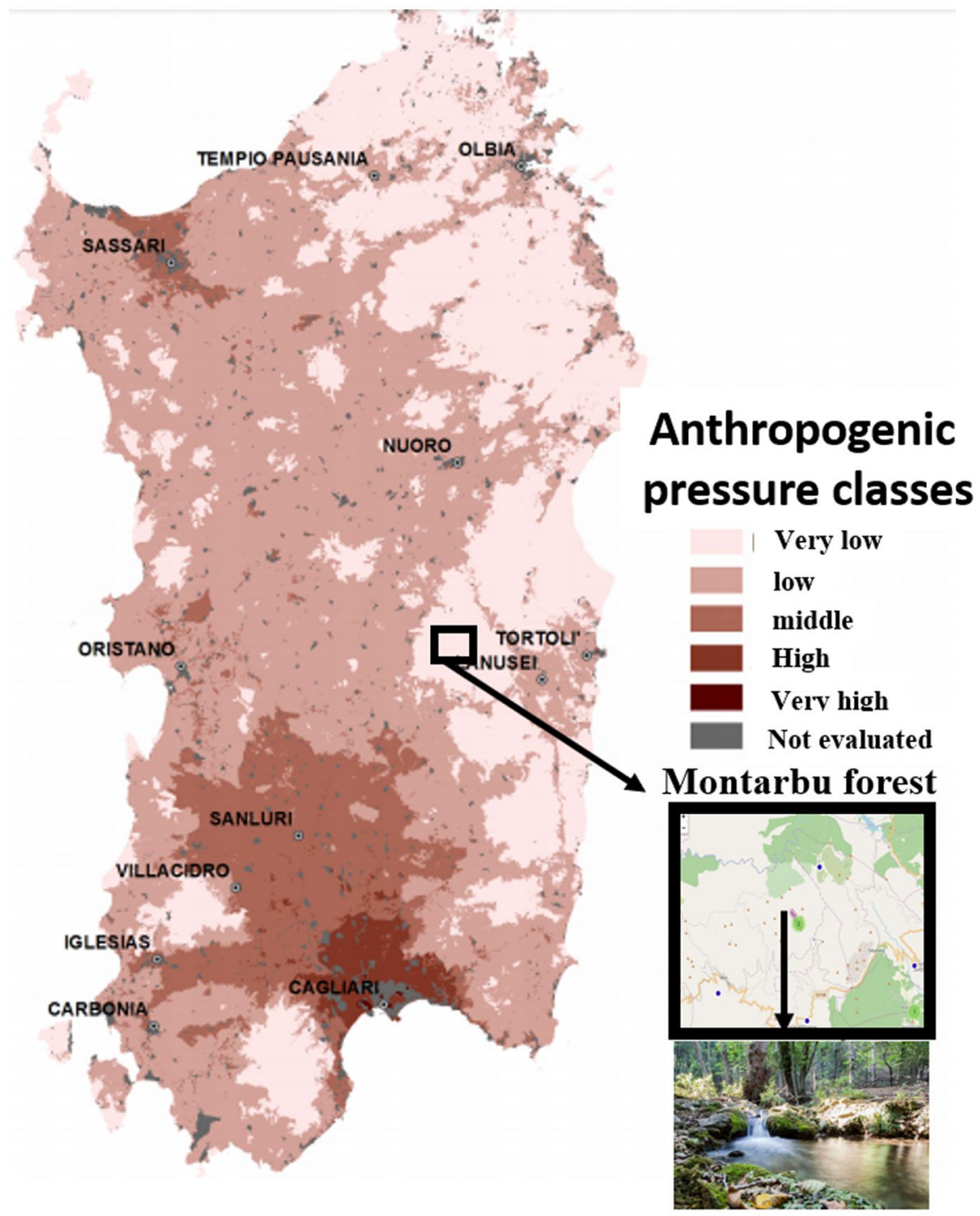

Rio Ermolinus $9^{\circ} 23^{\prime} \mathrm{E}$ ) located in the Montarbu Forest (Sardinia, Italy) (Fig. 1). The number of fish was determined following the indications in the USEPA Guidelines (USEPA, 2000).

The stream is characterized by clear, welloxygenated water, a moderately fast current, and the presence of waterfalls jumps, riffles runs, and pools. Moreover, the stream bed consists of sand, gravel, stones, and carbonate rocks. The carbonated part of the stream is characterized by travertine deposition (calcium carbonate) that occurs in various forms, cementing substrate particles in small dams. The abiotic parameters, water temperature,
$\mathrm{pH}$, water dissolved oxygen concentration, and water conductivity were recorded using a multiparameter probe (In Situ Inc. Smart Troll MP). Trout fish were captured using low-frequency, pulsed DC electrofishing. Stunned fishes were immediately killed by spiking the brain (WOAH, 2019), held in iceboxes and transported to the laboratory. Finally, samples were frozen until analysis.

Sample preparation

Brown trout were measured wet for total length (TL, $\mathrm{cm}$ ), from the snout tip to the fork of the tail to the 
nearest $0.1 \mathrm{~mm}$, using a manual calliper, and body weight $(\mathrm{BW}, \mathrm{g}$ ) was also determined. Then, the fish were dissected using a sharp stainless-steel scalpel, and all internal organs, including the intestine, stomach, liver, heart, kidneys, and swim bladder, were collected, weighed, and homogenized in a stainless-steel blender. The rest of the fish was separated from the head and homogenized in a stainless-steel blender. Before analysis, fish were stored in the refrigerator at $5{ }^{\circ} \mathrm{C}$ to avoid deterioration. Samples were then subjected to preparation for the analysis.

\section{Chemicals}

Hexane, ethyl ether, petroleum ether, and methanol were of analytical grade (Sigma Aldrich Chemie, Germany). $\mathrm{HNO}_{3}$ 67-(69\%), 30\% $\mathrm{H}_{2} \mathrm{O}_{2}$ solution, and standards of $\mathrm{Al}, \mathrm{AS}, \mathrm{B}, \mathrm{Ba}, \mathrm{Be}, \mathrm{Cd}, \mathrm{Co}, \mathrm{Cr}, \mathrm{Cu}$, $\mathrm{Fe}, \mathrm{Hg}, \mathrm{Mn}, \mathrm{Mo}, \mathrm{Ni}, \mathrm{Pb}, \mathrm{Sb}, \mathrm{Sn}, \mathrm{Sr}, \mathrm{Te}, \mathrm{Ti}, \mathrm{V}$, and Zn were of ICP grade (Carlo Erba Reagents Milan, Italy). $\mathrm{HCl}$ (34-37\%) of super-pure quality (Romil Spa Cambridge, England), $\mathrm{H}_{2} \mathrm{SO}_{4}$ (95-98\%), anhydrous $\mathrm{Na}_{2} \mathrm{SO}_{4}, \mathrm{CuSO}_{4} 5 \mathrm{H}_{2} \mathrm{O}, \mathrm{NaOH}(32 \%), \mathrm{H}_{2} \mathrm{SO}_{4} 0.5 \mathrm{~N}$, $\mathrm{NaOH} 0.5 \mathrm{~N}$, methyl red, $\mathrm{NaCl}, \mathrm{MgSO}_{4}$, and $\mathrm{KOH}$ were of analytical grade (Sigma Aldrich Chemie, Germany). A marine oil FAME mix analytical standard was purchased from Restek (Bellefonte, PA). Doubledeionized water was obtained with a Milli-Q water purification system (Millipore, Bedford, MA, USA).

\section{Moisture and ash}

Ten grams of homogenized EP and $5 \mathrm{~g}$ of gut sample were weighed in a porcelain crucible and dried at $100{ }^{\circ} \mathrm{C}$ in a thermostatic heater (Argolab, Milan, Italy) for $24 \mathrm{~h}$ to reach a constant weight, and analyzed for moisture content assessment. Samples were then heated to $500{ }^{\circ} \mathrm{C}$ for $5 \mathrm{~h}$ for carbonization and ash analysis. The moisture and ash contents were calculated as a percentage of the fresh weight (FW).

Total protein

According to the Kjeldahl digestion method, total protein was analyzed by using a BUCHI K-424 digestion unit and a BUCHI K314 distillation unit. Two grams of fresh homogenate EP and gut were weighed in a Speed-Digester flask and processed according to the method. Twenty millilitres of $\mathrm{H}_{2} \mathrm{SO}_{4}$ concentrate,
$0.5 \mathrm{~g}$ of sodium sulfate, and a tip of copper sulfate were added to the mineralization flask. After mineralization, the solution was left to cool, and $50 \mathrm{~mL}$ of Milli-Q $\mathrm{H}_{2} \mathrm{O}$ was added. When the solution reached a light blue colour, the flask was inserted into the distillation unit, and a concentrated solution of $\mathrm{NaOH}$ was added directly to the distiller. The distillation process started when the sample solution reached a brownishblack colour. Then, $100-150 \mathrm{~mL}$ of distillate was collected, and a known quantity of $0.5 \mathrm{~N}$ plus a few drops of methyl red were added. After distillation, quantitative analysis was performed by acid-base titration using $0.5 \mathrm{~N} \mathrm{NaOH}$.

$\%$ protein $=((\mathrm{a}-\mathrm{b}) * \mathrm{c} * 100 * \mathrm{~K}) / \mathrm{g}$ sample.

a: $\mathrm{mL}$ of $0.5 \mathrm{~N} \mathrm{H}_{2} \mathrm{SO}_{4}$ added to the collection flask.

b: mL of titrant used (10 mL of $\mathrm{NaOH} 0.5 \mathrm{~N})$.

c: conversion factor $\mathrm{mL}$ of $\mathrm{H}_{2} \mathrm{SO}_{4} 0.5 \mathrm{~N}$ in $\mathrm{g}$ of nitrogen (0.007).

$\mathrm{K}$ : general nitrogen-protein conversion factor (6.25).

\section{Total lipid}

One gram of fresh homogenized EP and gut were accurately weighed and extracted using the rapid extraction system for solid-liquid extraction Soxtherm (C-Gerhardt, Analytical Systems, Konigswinter, Germany) with a $150-\mathrm{mL}$ mixture of ethylic ether/ petroleum ether (1/1). The fat content was determined gravimetrically by weighing the boiling flask after evaporation from the extracting solvents.

Fatty acid analysis

Fatty acid analysis was carried out according to Angioni and Addis (2014). Briefly: $1 \mathrm{~g}$ of EP and gut were weighed in a $15-\mathrm{mL}$ screw-capped falcon tube, and then $2 \mathrm{~mL}$ of hexane, $1 \mathrm{~g}$ of $\mathrm{NaCl}$, and $0.5 \mathrm{~g}$ of $\mathrm{MgSO}_{4}$ were added. The falcon tube was shaken for $3 \mathrm{~min}$ in a vortex, shaken for $15 \mathrm{~min}$ with a rotary shaker, and then centrifuged at $4000 \mathrm{rpm}$ for $10 \mathrm{~min}\left(10^{\circ} \mathrm{C}\right.$ temperature). Transesterification was carried out as follows: $500 \mu \mathrm{L}$ of hexane extract and $200 \mu \mathrm{L}$ of alcoholic potash (KOH $2 \mathrm{~N}$ in $\mathrm{MeOH}$ ) were heated and agitated in a vortex for $4 \mathrm{~min}$. The organic phase was injected into the GC-MS instrument for analysis. A TRACE GC ULTRA Single Quad DSQ mass detector (Thermo Finnigan, Milan, Italy) equipped with a COMBI PAL autosampler (CTC Analytics, Zwingen, Switzerland), and a split/splitless injector was used. The analytical column was a Varian Factor 
Four VFWAX column $(60 \mathrm{~m} \times 0.25 \mathrm{~mm}$ i.d. $\times 0.25-\mu \mathrm{m}$ film thickness) (Varian, Milan, Italy); helium was the carrier gas at $1 \mathrm{~mL} / \mathrm{min}$. The sample $(1 \mu \mathrm{L})$ was injected in splitless mode $(1 \mathrm{~min})$. The mass spectrometer was operated with electron impact (EI) ionization and positive mode, with a solvent delay of $5.5 \mathrm{~min}$. The injector, ion source, and transfer line temperatures were 50, 200, and $250{ }^{\circ} \mathrm{C}$, respectively. Peak identification was performed comparing full mass spectra $(50-550 \mathrm{~m} / \mathrm{z})$ and retention times (r.t.) from authentic standards and NIST MS Spectra Library (NIST/EPA/NIH Mass Spectral Library, 2017, Ver. 2.3).

Heavy metal and metalloid analysis

Approximately $0.2 \mathrm{~g}$ of ash was accurately weighed and digested with $1.25 \mathrm{~mL}$ of $67 \% \mathrm{HNO}_{3}, 3.75 \mathrm{~mL}$ of $34 \%$ $\mathrm{HCl}$ and $1 \mathrm{~mL}$ of $30 \% \mathrm{H}_{2} \mathrm{O}_{2}$ in closed polytetrafluoroethylene (PTFE) tubes using a CEM MARS 6 microwave digestion system (CEM SRL, Italy). A one-stage protocol was used as follows: heating time, $13 \mathrm{~min}$; pressure, 100 PSI; and power, $600 \mathrm{~W}$. After digestion, the solution was left to cool at room temperature, placed in a $10-\mathrm{mL}$ flask, diluted to the mark with double-deionized water, and filtered through a $0.45-\mu \mathrm{m}$ nitrocellulose membrane filter. Control solvent samples were simultaneously prepared to avoid false positives and contamination during analysis. $\mathrm{Hg}$ and As sample preparations were carried out using an Agilent VGA-77 instrument (Agilent, Milan, Italy) according to the manufacturer instructions (Beach, 2010; Evans et al., 2010). Analysis was carried out using a Varian 710ES ICP optical emission spectrometer (Agilent, Milan, Italy), according to Corrias et al. (2020b). Each measurement was conducted in triplicate. The limits of detection (LODs) and the limits of quantitation (LOQs) were calculated as three and ten times the standard deviation reading of the blank sample signal, respectively. Calibration curves were calculated with five points starting from the LOQ value and were considered acceptable when $r^{2} \geq 0.995$.

\section{Risk assessment}

\section{Non-carcinogenic risk evaluation}

The target hazard quotients (THQ) index was applied to assess the potential non-cancer risk associated with consumption of the trout sampled and calculated following the USEPA guidelines (1989) (1):

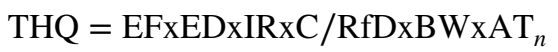

The average body weight for an adult consumer of $67 \mathrm{~kg}$ and an average fish intake rate (IR) of $0.036 \mathrm{~kg} /$ day for a person (FAO, 2020) were considered for the THQ calculation (SI trout Table A). The reference doses (RfDs) for oral intake were obtained from the (Integrated Risk Information System 2020; USEPA, 2010). The THQ values were calculated for the traditional edible part and the sum of EP and the gut. THQ values exceeding " 1 " indicate a potential health risk to consumers (USEPA, 1989). Regarding $\mathrm{Hg}$, we considered the RfD of methyl mercury, assuming that all mercury found was in this organic form $(\mathrm{MeHg})$.

\section{Carcinogenic risk evaluation}

As $\mathrm{Cd}$ and $\mathrm{Pb}$ are known to pose a risk of cancer (IARC, 2012). IARC has classified MeHg as "possibly carcinogenic to humans" (IARC, 2012), whereas the US Environmental Protection Agency (USEPA) has established that evidence of $\mathrm{MeHg}$ carcinogenicity in humans is insufficient. Indeed, the rationale of the carcinogenicity in experimental animals was restricted; therefore, the USEPA has designated $\mathrm{MeHg}$ as a Group C material (possible human carcinogen). Since the CPSo (Carcinogenic Potency Slope oral) of $\mathrm{Cr}$ and $\mathrm{Hg}$ has not been published by the USEPA, TR (Target Cancer Risk) was calculated only for As $(\mathrm{CPSo}=1.5 \mathrm{mg} / \mathrm{kg} /$ day $), \mathrm{Cd}(\mathrm{CPSo}=6.3 \mathrm{mg} /$ $\mathrm{kg} /$ day $)$, and $\mathrm{Pb} \quad\left(\mathrm{CPSo}=8.5 \times 10^{-3} \mathrm{mg} / \mathrm{kg} /\right.$ day $)$ (USEPA, 2010). The risk of cancer was estimated as the probability of an individual developing cancer over a lifetime as a result of exposure to potential carcinogens using the target cancer risk (TR) (2):

$\mathrm{TR}=\mathrm{EFxEDxIRxCP}_{\mathrm{o}} \mathrm{xC} / \mathrm{BWxAT}_{\mathrm{c}}$

The exposure duration (average lifetime) was set at 83 years, the average life expectancy (both sexes) in Italy. Acceptable risk levels for carcinogens have been set in the range from $10^{-4}$ to $10^{-6}$.

\section{Statistical analysis}

Analysis of variance (ANOVA) was carried out with XLSTAT software (Addinsolf LTD, Version 19.4). Mean comparisons of the effects of treatments were 
calculated by Fisher's least significant difference test at $\mathrm{p} \leq 0.05$. ICP-OES, GC/MS fatty acid, and lipid analysis data were analyzed with SIMCA 14 (Umetrics $\mathrm{AB}$, Umea, Sweden) for principal component analysis (PCA). The coefficient of determination (R2) was considered to evaluate the correlation between the lipid fraction and metals accumulation (Atherton et al., 2006).

\section{Results}

Samples of brown trout ranged from 83.52 to $140.48 \mathrm{~g}$ in body weight (BW) and from 15.19 to $25.53 \mathrm{~cm}$ in total length (TL), while the gut weight ranged from approximately $10.56 \pm 8.91 \mathrm{~g}( \pm \mathrm{RSD})$. The EP's water and ash contents were $74.83 \pm 1.38$ and $2.66 \pm 11.21 \mathrm{~g} / 100 \mathrm{~g} \mathrm{FW}$, respectively, which were slightly higher than the gut content (Table 1). Protein and lipids accounted in for $17.84 \pm 3.19 \mathrm{~g} / 100 \mathrm{~g}$ FW and $4.67 \pm 19.26 \mathrm{~g} / 100 \mathrm{~g}$ FW $(\mathrm{g} \pm \mathrm{RSD} \%)$, respectively (Table 1), whereas in the gut were $11.51 \pm 8.09$, and $2.23 \pm 19.10(\mathrm{~g} \pm \mathrm{RSD} \%)$. SAFAs $(36.64 \pm 4.35 \%)$ and MUFAs $(36.00 \pm 4.41 \%)$ were the most abundant fatty acids, followed by PUFAs $(27.34 \pm 4.20 \%$ ) (Table 2). Gut fatty acid followed PUFA $>$ MUFA $>$ SAFA, accounting for $37.74 \pm 8.78 \%, 23.92 \pm 13.35 \%$ and $14.67 \pm 8.81 \%$, respectively (Table 2 ).

The $\mathrm{C} 16$ and $\mathrm{C} 18$ families were the most represented among SAFAs, MUFAs, and PUFAs. C18:3 $\alpha$ $(4.79 \pm 10.55 \%)$, EPA $(2.56 \pm 11.29 \%)$, and DHA $(1.14 \pm 13.64)$ were also present in considerable amounts (Table 3); $\omega 3$ families accounted $8.84 \pm 7.07 \%$; and $\omega 6$ fatty acids accounted for $15.75 \pm 6.40 \%$, leading to a $\omega 3 / \omega 6$ ratio of $0.56 \pm 6.15$ in EP, whereas in the gut $\omega 3$ accounted $21.13 \pm 11.80 \%$ and $\omega 616.61 \pm 10.12 \%$, with a ratio $\omega 3 / \omega 61.28 \pm 12.22 \%$ (Table 2).

The ICP-OES method allowed the detection and quantitation of 22 metals, with calibration curves
Table 2 Fatty acid composition (\%) of trout muscles collected from Sardinia mounting streams

\begin{tabular}{lcc}
\hline & Muscles & Gut \\
\hline$\Sigma$ saturated & $36.64 \pm 4.35$ & $14.67 \pm 8.81$ \\
$\Sigma$ Monounsaturated & $36.00 \pm 4.41$ & $23.92 \pm 13.35$ \\
$\Sigma$ polyunsaturated & $27.34 \pm 4.20$ & $37.74 \pm 8.78$ \\
$\Sigma$ FFA & $0.026 \pm 6.54$ & - \\
PUFA/SAFA & $0.75 \pm 14.48$ & $2.59 \pm 12.11$ \\
$\Sigma \omega 3(\%)$ & $8.84 \pm 7.07$ & $21.13 \pm 11.80$ \\
$\Sigma \omega 6(\%)$ & $15.75 \pm 6.40$ & $16.61 \pm 10.12$ \\
๑3/の6 & $0.56 \pm 6.15$ & $1.28 \pm 12.22$ \\
\hline
\end{tabular}

with correlation coefficients ranging from 0.9922 to 0.9999 , and LOQ values suitable for the analysis and in line with literature data (Wenzl et al., 2016) (Table 4). Be, Co, Mo, Sb, Sn, and Te were not detected in any samples. The detected metals and metalloids showed high variability among the different fishes. $\mathrm{Fe}, \mathrm{Al}, \mathrm{Hg}$, As, and $\mathrm{Mn}$ showed relatively high gut concentrations, with residue values of $226.98 \pm 39.18, \quad 80.69 \pm 41.90, \quad 12.23 \pm 16.16$, $10.57 \pm 44.03$, and $8.39 \pm 32.67 \mu \mathrm{g} \cdot \mathrm{g}^{-1}( \pm \mathrm{RSD} \%)$, respectively. In contrast, the other metals and metalloids showed values in the range of $0.03 \pm 25.02$ (Cd) and $4.89 \pm 65.56 \mu \mathrm{g} \cdot \mathrm{g}^{-1}(\mathrm{Cu})$ (Table 4). The EP showed general values always below the gut, with the most abundant metals being $\mathrm{Cu}\left(1.19 \pm 60.87 \mu \mathrm{g} \mathrm{g}^{-1}\right)$, $\mathrm{Zn}\left(0.97 \pm 15.96 \mu \mathrm{g} \mathrm{g}^{-1}\right), \mathrm{Ba}\left(0.80 \pm 38.48 \mu \mathrm{g} \mathrm{g}^{-1}\right), \mathrm{Al}$ $\left(0.70 \pm 55.10 \mu \mathrm{g} \mathrm{g}^{-1}\right)$, and $\mathrm{Sr}\left(0.67 \pm 16.70 \mu \mathrm{g} \mathrm{g}^{-1}\right)$. Moreover, As, B, Ni, and Ti were absent in the edible part (Table 4).

Non-carcinogenic risk assessment calculated considering a regular intake of approximately $0.036 \mathrm{~kg} /$ day fish resulted in THQ values below 1 for each metal in the EP, with maximum and minimum values ranging from $4.30 \times 10^{-1}(\mathrm{Hg})$ and $2.87 \times 10^{-5}(\mathrm{Cr})$, respectively (Table 5$)$. Also, the intake of EP plus the gut showed the minimum

Table 1 Chemical-physical parameters of the fish used in the experiment

\begin{tabular}{lllllll}
\hline & $\begin{array}{l}\text { Average weight } \\
\mathrm{g} \pm \mathrm{RSD} \%\end{array}$ & \% whole fish & $\begin{array}{l}\text { Humidity } \\
\mathrm{g} / 100 \mathrm{~g} \mathrm{FW} *\end{array}$ & $\begin{array}{l}\text { Ash } \\
\mathrm{g} / 100 \mathrm{~g} \mathrm{FW}\end{array}$ & $\begin{array}{l}\text { Total protein } \\
\mathrm{g} / 100 \mathrm{~g} \mathrm{FW}\end{array}$ & $\begin{array}{l}\text { Total lipid } \\
\mathrm{g} / 100 \mathrm{~g} \mathrm{FW}\end{array}$ \\
\hline Muscles & $93.51 \pm 17.41$ & $89.44 \pm 1.05$ & $74.83 \pm 1.38$ & $2.66 \pm 11.21$ & $17.84 \pm 3.19$ & $4.67 \pm 19.26$ \\
Gut & $11.02 \pm 18.79$ & $10.56 \pm 8.91$ & $70.07 \pm 2.29$ & $2.10 \pm 8.15$ & $11.51 \pm 8.09$ & $2.23 \pm 19.10$ \\
\hline
\end{tabular}

${ }^{*} \mathrm{~g} / 100 \mathrm{~g} \pm \mathrm{RSD} \%$ 
Table 3 Fatty acid composition (\%) of the lipid fraction extracted from the muscles of the brown trout

\begin{tabular}{|c|c|}
\hline Fatty acid & Trout muscles \\
\hline $\mathrm{C} 14: 0$ & $3.36 \pm 13.76$ \\
\hline anteiso C15:0 & $0.44 \pm 14.18$ \\
\hline $\mathrm{C} 15: 0+$ isomer & $0.39 \pm 16.79$ \\
\hline anteiso $\mathrm{C} 16$ & $0.13 \pm 16.46$ \\
\hline $\mathrm{C} 16: 0$ & $25.61 \pm 4.92$ \\
\hline $\mathrm{C} 17: 0$ & $0.10 \pm 17.07$ \\
\hline $\mathrm{C} 17: 0$ anteiso $\mathrm{C} 18$ & $0.47 \pm 13.13$ \\
\hline C18:0 & $5.29 \pm 8.18$ \\
\hline C20:0 & $0.17 \pm 9.80$ \\
\hline $\mathrm{C} 14: 1$ & $0.21 \pm 12.25$ \\
\hline C16:1 & $14.31 \pm 12.82$ \\
\hline C16:1 n9 7 methyl & $0.49 \pm 11.95$ \\
\hline $\mathrm{C} 17: 1$ & $0.50 \pm 17.25$ \\
\hline C18:1c & $16.52 \pm 13.31$ \\
\hline $\mathrm{C} 18: 1 \Delta 11$ & $3.60 \pm 9.47$ \\
\hline C20:1 & $0.36 \pm 17.13$ \\
\hline $\mathrm{C} 16: 2$ & $1.20 \pm 7.54$ \\
\hline $\mathrm{C} 18: 2$ & $14.28 \pm 6.61$ \\
\hline $\mathrm{C} 18: 2 \mathrm{n} 6 \mathrm{c}$ & $0.33 \pm 12.65$ \\
\hline C18:3 & $0.24 \pm 39.66$ \\
\hline $\mathrm{C} 18: 3 \alpha$ & $4.79 \pm 10.55$ \\
\hline $\mathrm{C} 18: 4 \mathrm{n} 3$ & $0.62 \pm 12.31$ \\
\hline $\mathrm{C} 20: 2$ & $0.45 \pm 12.08$ \\
\hline C20:3 & $0.27 \pm 13.76$ \\
\hline C20:4 & $0.70 \pm 15.43$ \\
\hline C20:3n3 (11-14-17) & $0.13 \pm 15.14$ \\
\hline $\mathrm{C} 20: 4 \mathrm{n} 3$ & $0.22 \pm 16.51$ \\
\hline C20:5 EPA & $2.56 \pm 11.29$ \\
\hline $\mathrm{C} 22: 5$ & $0.42 \pm 13.74$ \\
\hline C22:6 DHA & $1.14 \pm 13.64$ \\
\hline MonoM $(9,5)$ FA & $0.009 \pm 12.75$ \\
\hline Dime $(9,5) \mathrm{FA}$ & $0.001 \pm 23.87$ \\
\hline DiMe $(11,3) \mathrm{FA}$ & $0.011 \pm 14.38$ \\
\hline MonoM $(11,5) \mathrm{FA}$ & $0.0004 \pm 14.93$ \\
\hline Dime $(11,5) \mathrm{FA}$ & $0.005 \pm 9.57$ \\
\hline
\end{tabular}

THQ values for $\mathrm{Cr}\left(7.16 \times 10^{-5}\right)$ and maximum values for As and $\mathrm{Hg}$ of 18.93 and 66.14, respectively (Table 5).

Carcinogenic risk expressed as TR showed values for $\mathrm{Cd}$ and $\mathrm{Pb}$ of $1.02 \times 10^{-4}$ and $9.13 \times 10^{-7}$ in the $\mathrm{EP}$ and $2.03 \times 10^{-4}$ and $4.06 \times 10^{-6}$ in the $\mathrm{EP}+$ gut. As residues in the EP were below the LOQ of the analytical method, the TR calculated for the total fish was ascribable only to the gut's contamination $\left(8.52 \times 10^{-3}\right)$.

Principal component analysis (PCA) was used to verify the correlation between metals and metalloid accumulation and the lipidic or fatty acid amount in the gut and EP. The analysis of PCA biplot score and loadings for gut showed that the samples of trout had an uneven composition (Fig. 2); however, the lipid fraction showed a fairly good correlation with $\mathrm{Cd}$ (0.7207) and Hg (0.7557). The PCA biplot loadings showed for total lipids a significant influence along the PC2 axis of the variable $\mathrm{Hg}, \mathrm{Cd}$, and $\mathrm{Pb}$, whereas $\mathrm{Cd}$ and $\mathrm{Pb}$ contribute for SAFA and $\mathrm{Cd}$ and $\mathrm{Hg}$ for MUFA; PUFAs were not correlated to heavy metal accumulation in the gut (Fig. 3a).

Correlation analysis for EP showed a fairly good correlation among total lipids (between 0.539 and 0.7877), $\mathrm{Cd}, \mathrm{Pb}, \mathrm{Cu}, \mathrm{Fe}$, and $\mathrm{Cr}$, whereas MUFA showed a low correlation with $\mathrm{Cd}(0.4737)$ and $\mathrm{Hg}$ (0.4312), PUFA a negative correlation with $\mathrm{Al}$ $(-0.6481)$ and $\mathrm{Cd}(-0.4805)$, and SAFA had no correlation with metals accumulation. The most influencing variables for total lipids loadings were $\mathrm{Cd}, \mathrm{Pb}$, and $\mathrm{Cu}$ along the $\mathrm{PC} 1$ axis and MUFA $\mathrm{Cd}, \mathrm{Hg}$, and $\mathrm{Zn}$. SAFA and PUFA fell in the PC1 negative loadings and did not influence metals accumulation (Fig. 3b).

PCA emphasizes the differences in accumulation between the two matrices; $\mathrm{Pb}$ and $\mathrm{Hg}$ were the most discriminating along the $\mathrm{PC} 1$ axis, while $\mathrm{Cd}$ was the most discriminating on the PC2 axis (Fig. 2).

\section{Discussion}

Wild brown trout in nature usually feed on invertebrates belonging to terrestrial and aquatic communities (Fochetti et al., 2003). Feeding patterns affect both lipid and protein profiles in a relevant way $(\mathrm{Oz}, 2016)$. Therefore, the profile of fatty acids can change drastically, and the degree of correlation with the diet is not always unambiguous $(\mathrm{Oz}$, 2019; Aziz et al., 2013; Trbovic et al., 2012; Bell \& Dick, 2004). Sardinian brown trout mainly feed on aquatic insects (Massidda et al., 2008), which present fatty acid compositions with comparable amounts of SAFAs and MUFAs and low levels of PUFAs (Fontaneto et al., 2011; Kiyashko et al., 2004; Shipley et al., 2012), reflecting the composition found in this paper. 
Table 4 Concentration of metals and metalloids $\left(\mu \mathrm{g} \mathrm{g}^{-1}, \mathrm{FW}\right)$ in guts and muscle of brown trout

\begin{tabular}{|c|c|c|c|c|c|c|c|}
\hline Metal & $\lambda$ & MRL, $\mu \mathrm{g} \mathrm{g}^{-1}$ & $\mathrm{LOQ}, \mu \mathrm{g} \mathrm{g}^{-1}$ & Linear regression equation & $\mathrm{R}^{2}$ & Gut, $\mu \mathrm{g} \mathrm{g}^{-1} \pm \mathrm{RSD}$ & Muscle, $\mu \mathrm{g} \mathrm{g}^{-1} \pm \mathrm{RSD}$ \\
\hline $\mathrm{Al}$ & 237.3 & & 0.10 & $y=717.36 x+12.11$ & 0.9990 & $80.69 \pm 41.90$ & $0.70 \pm 55.10$ \\
\hline AS & 188.98 & & 0.10 & $y=79.21 x-11.44$ & 0.9996 & $10.57 \pm 44.03$ & $<\mathrm{LOQ}$ \\
\hline $\mathrm{B}$ & 249.77 & & 0.025 & $y=5251 x+789.8$ & 0.9997 & $2.80 \pm 36.32$ & $<\mathrm{LOQ}$ \\
\hline $\mathrm{Ba}$ & 493.40 & & 0.005 & $y=8019-417.3$ & 0.9995 & $4.22 \pm 16.70$ & $0.80 \pm 38.48$ \\
\hline $\mathrm{Be}$ & 313.04 & & 0.005 & $y=114,687 x-10,873$ & 0.9989 & $<$ LOQ & $<$ LOQ \\
\hline $\mathrm{Cd}$ & 226.50 & 0.05 & 0.005 & $y=15,189 x+3513$ & 0.9922 & $0.03 \pm 25.02$ & $0.03 \pm 18.65$ \\
\hline Co & 228.61 & & 0.025 & $y=2213 x-3.07$ & 0.9998 & $<$ LOQ & $<$ LOQ \\
\hline $\mathrm{Cr}$ & 267.71 & & 0.005 & $y=10,136 x-23$ & 0.9999 & $0.12 \pm 27.14$ & $0.08 \pm 23.95$ \\
\hline $\mathrm{Cu}$ & 324.75 & & 0.01 & $y=17,524 x-363$ & 0.9997 & $4.89 \pm 65.56$ & $1.19 \pm 60.87$ \\
\hline $\mathrm{Fe}$ & 259.94 & & 0.01 & $y=3069 x+150$ & 0.9995 & $226.98 \pm 39.18$ & $0.30 \pm 34.79$ \\
\hline $\mathrm{Hg}$ & 194.16 & 0.50 & 0.05 & $y=397 x+47$ & 0.9998 & $12.23 \pm 16.16$ & $0.08 \pm 14.89$ \\
\hline $\mathrm{Mn}$ & 257.61 & & 0.005 & $y=108,182 x-588$ & 0.9996 & $8.39 \pm 32.67$ & $0.04 \pm 22.33$ \\
\hline Mo & 204.59 & & 0.10 & $y=450 x-46$ & 0.9959 & $<$ LOQ & $<$ LOQ \\
\hline $\mathrm{Ni}$ & 216.55 & & 0.025 & $y=1699 x-19$ & 0.9997 & $0.11 \pm 44.40$ & $<\mathrm{LOQ}$ \\
\hline $\mathrm{Pb}$ & 220.35 & 0.3 & 0.05 & $y=329 x+16$ & 0.9989 & $0.69 \pm 48.42$ & $0.20 \pm 48.85$ \\
\hline $\mathrm{Sb}$ & 217.58 & & 0.50 & $y=46 x-10$ & 0.9981 & $<$ LOQ & $<$ LOQ \\
\hline $\mathrm{Sn}$ & 189.92 & & 0.50 & $y=79 x+1$ & 0.9990 & $<$ LOQ & $<\mathrm{LOQ}$ \\
\hline $\mathrm{Sr}$ & 407.77 & & 0.005 & $y=827,346 x+17,943$ & 0.9991 & $0.38 \pm 15.49$ & $0.67 \pm 16.70$ \\
\hline $\mathrm{Te}$ & 214.28 & & 0.50 & $y=116 x+7$ & 0.9974 & $<$ LOQ & $<$ LOQ \\
\hline $\mathrm{Ti}$ & 336.12 & & 0.10 & $y=14,629 x+1965$ & 0.9989 & $1.12 \pm 19.96$ & $<$ LOQ \\
\hline V & 292.40 & & 0.005 & $y=14,788 x-37$ & 0.9998 & $0.14 \pm 27.77$ & $0.01 \pm 26.34$ \\
\hline $\mathrm{Zn}$ & 213.85 & & 0.025 & $y=5027 x-50$ & 0.9991 & $0.78 \pm 25.19$ & $0.97 \pm 15.96$ \\
\hline
\end{tabular}

The bioaccumulation of persistent contaminants in living organisms depends on on-site pollution, detoxification rate, and metabolism (Jakimska et al.,
2011). This phenomenon directly affects both fish tissues and organs, leading to increased fish mortality due to exceeding acute limits (Davidson et al., 2009;

Table 5 Target hazard quotients (THQ) and target cancer risk (TR) caused by consuming brown trout muscles and gut

\begin{tabular}{lllllll}
\hline Metal & RfD, mg/kg/day & THQ muscles & THQ gut +muscle & CPS, mg/kg/day & TR muscles & TR gut + muscle \\
\hline $\mathrm{Al}$ & 1.0 & $3.76 \times 10^{-04}$ & $4.37 \times 10^{-02}$ & - & - & - \\
$\mathrm{AS}$ & $3.0 \times 10^{-04}$ & - & 18.93 & 1.5 & - & $8.52 \times 10^{-3}$ \\
$\mathrm{~B}$ & $2.0 \times 10^{-01}$ & - & $7.52 \times 10^{-03}$ & - & - \\
$\mathrm{Ba}$ & $2.0 \times 10^{-01}$ & $2.15 \times 10^{-03}$ & $1.35 \times 10^{-02}$ & - & - & - \\
$\mathrm{Cd}$ & $1.0 \times 10^{-03}$ & $1.61 \times 10^{-02}$ & $3.22 \times 10^{-02}$ & 6.3 & $1.02 \times 10^{-4}$ & $2.03 \times 10^{-4}$ \\
$\mathrm{Cr}$ & 1.5 & $2.87 \times 10^{-05}$ & $7.16 \times 10^{-05}$ & - & - \\
$\mathrm{Cu}$ & $4.0 \times 10^{-02}$ & $1.60 \times 10^{-02}$ & $8.17 \times 10^{-02}$ & - & - \\
$\mathrm{Fe}$ & $7.0 \times 10^{-01}$ & $2.30 \times 10^{-04}$ & $1.74 \times 10^{-01}$ & - & - & - \\
$\mathrm{Hg}$ & $1.0 \times 10^{-04}$ & $4.30 \times 10^{-01}$ & 66.14 & - & - \\
$\mathrm{Mn}$ & $1.4 \times 10^{-01}$ & $1.54 \times 10^{-04}$ & $3.24 \times 10^{-02}$ & - & - & - \\
$\mathrm{Ni}$ & $2.0 \times 10^{-02}$ & - & $2.96 \times 10^{-03}$ & - & - & - \\
$\mathrm{Pb}$ & $3.5 \times 10^{-03}$ & $3.07 \times 10^{-02}$ & $1.37 \times 10^{-01}$ & $8.5 \times 10^{-03}$ & $9.13 \times 10^{-7}$ & $4.06 \times 10^{-6}$ \\
$\mathrm{Sr}$ & $6.0 \times 10^{-01}$ & $6.00 \times 10^{-04}$ & $9.40 \times 10^{-04}$ & - & - & - \\
$\mathrm{Ti}$ & - & - & - & - & - & - \\
$\mathrm{V}$ & $9.0 \times 10^{-03}$ & $5.97 \times 10^{-04}$ & $8.96 \times 10^{-03}$ & - & - \\
$\mathrm{Zn}$ & $3.0 \times 10^{-01}$ & $1.74 \times 10^{-03}$ & $3.13 \times 10^{-03}$ & - & -
\end{tabular}




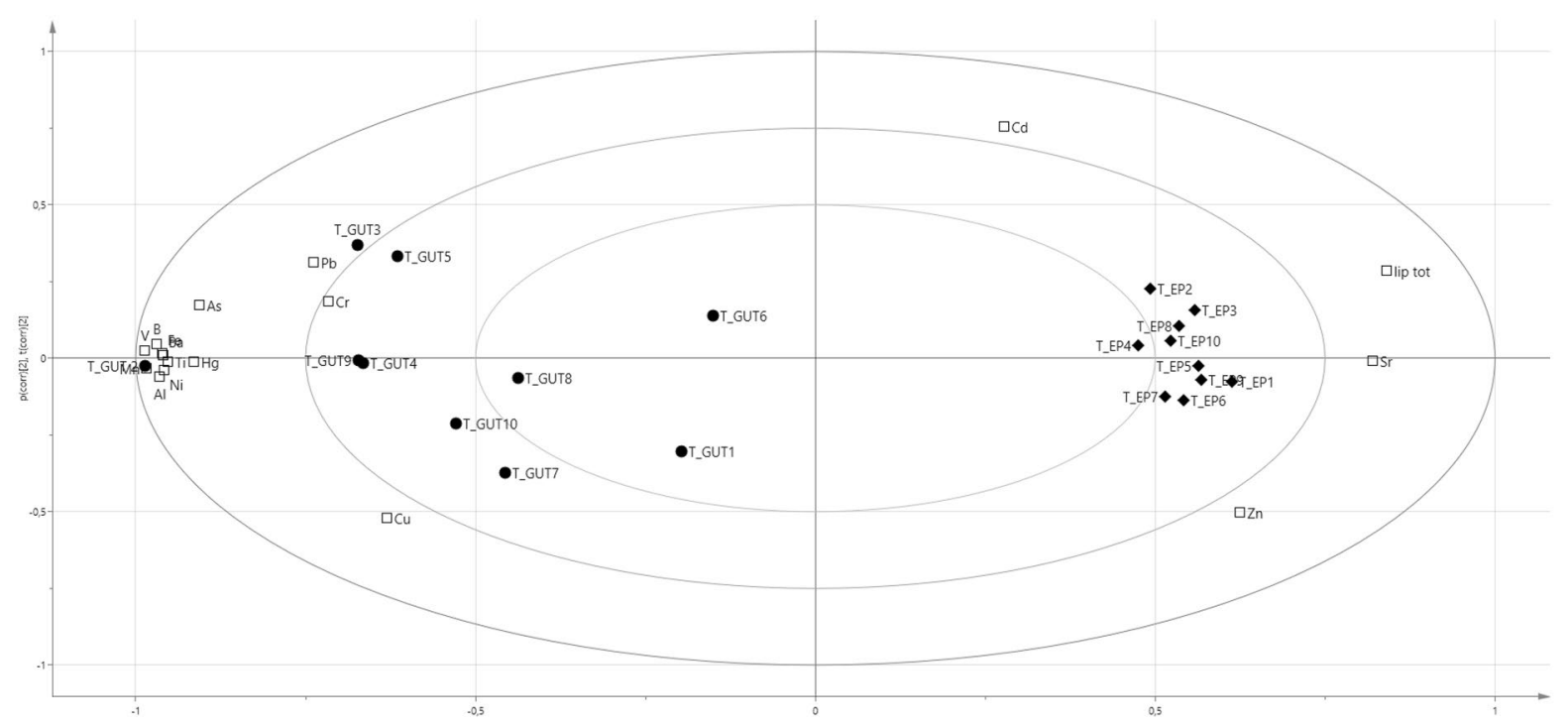

Fig. 2 The analysis of PCA biplot score and loadings

Pasha, 2016). Also, a transfer of contaminants to humans through the food chain may occur. Biomonitoring studies represent a necessary tool to evaluate the environmental behaviour of elements potentially harmful for both humans and other living organisms (Corrias et al., 2020b). Anthropogenic activities are considered the primary source of metal pollution in aquatic ecosystems. Thus, several studies in the literature deal with human activities' effect on environmental wellbeing, especially concerning heavy metal pollution from industrial waste (Gaur et al., 2020; Masindi \& Muedi, 2018).

Data on the bioaccumulation of metals and metalloids in aquatic organisms related to the surrounding environment's natural and geological characteristics are still lacking. However, some data showed an increased concentration of metals in volcanic soils and surrounding groundwater (Andronico et al., 2009; Buat-Menard \& Arnold, 1978; Favalli et al., 2004). Cyclic siliciclastic depositions characterize the Montarbu area in the water basin. Stratigraphy showed episodic deposition of carbonate beds and volcanic products (Costamagna, 2019). Mica from the phyllosilicate family formed by parallel sheets of silicate that characterize the Ermolinus River shows residues of $\mathrm{Al}, \mathrm{K}, \mathrm{Mn}, \mathrm{Fe}, \mathrm{Zn}$ and $\mathrm{Ca}$ (Charette \& Sholkovitz, 2006). Moreover, volcanic terrains can show high $\mathrm{Ba}$, As, and Hg levels from the Earth's crust and poured onto the ground over centuries through volcanic eruptions (WHO, 2011).

The Ermolinus River is in the inner part of the Montarbu forest, which is an area with shallow anthropogenic class pressure (Fig. 1), is hard to reach, and is not subjected to wind coming from polluted areas. The chemical-physical characteristics of the Ermolinus stream showed ideal values for life in freshwater streams, indicating a healthy ecosystem. With a temperature of $15.2{ }^{\circ} \mathrm{C}$ in the May/ June period, Ermolinus river water showed good resilience to the atmospheric temperature $\left(20^{\circ} \mathrm{C}\right)$ (SI Trout Table B). The $\mathrm{pH}$ at 7.5 was in the middle of the range for potable freshwater established by the OMS (6.5-8.5) and was weakly basic (WHO, 2007). The $\mathrm{pH}$ value influences metals' solubility; $\mathrm{Fe}$ and $\mathrm{Cu}$ are more soluble at $\mathrm{pH}$ values $<7$, and $\mathrm{Al}$ and $\mathrm{Zn}$ are more soluble at $\mathrm{pH}$ values $>10$. Moreover, this value corresponds to the $\mathrm{pH}$ of fish blood and therefore maintains the body's homeostasis. The dissolved oxygen content was $8.33 \mathrm{mg} / \mathrm{L}$, within the suggested range of 7-11 mg/L (Rounds et al., 2013). Mountain rivers, belonging from rainfalls and melting snow, show conductivity values below $50 \mu \mathrm{S} / \mathrm{cm}$, while levels above $500 \mu \mathrm{S} / \mathrm{cm}$ can be found in lowland rivers, where inorganic matter can accumulate from sediments and natural origin. The conductivity value detected in the Ermolinus River $(648 \mu \mathrm{S} /$ 

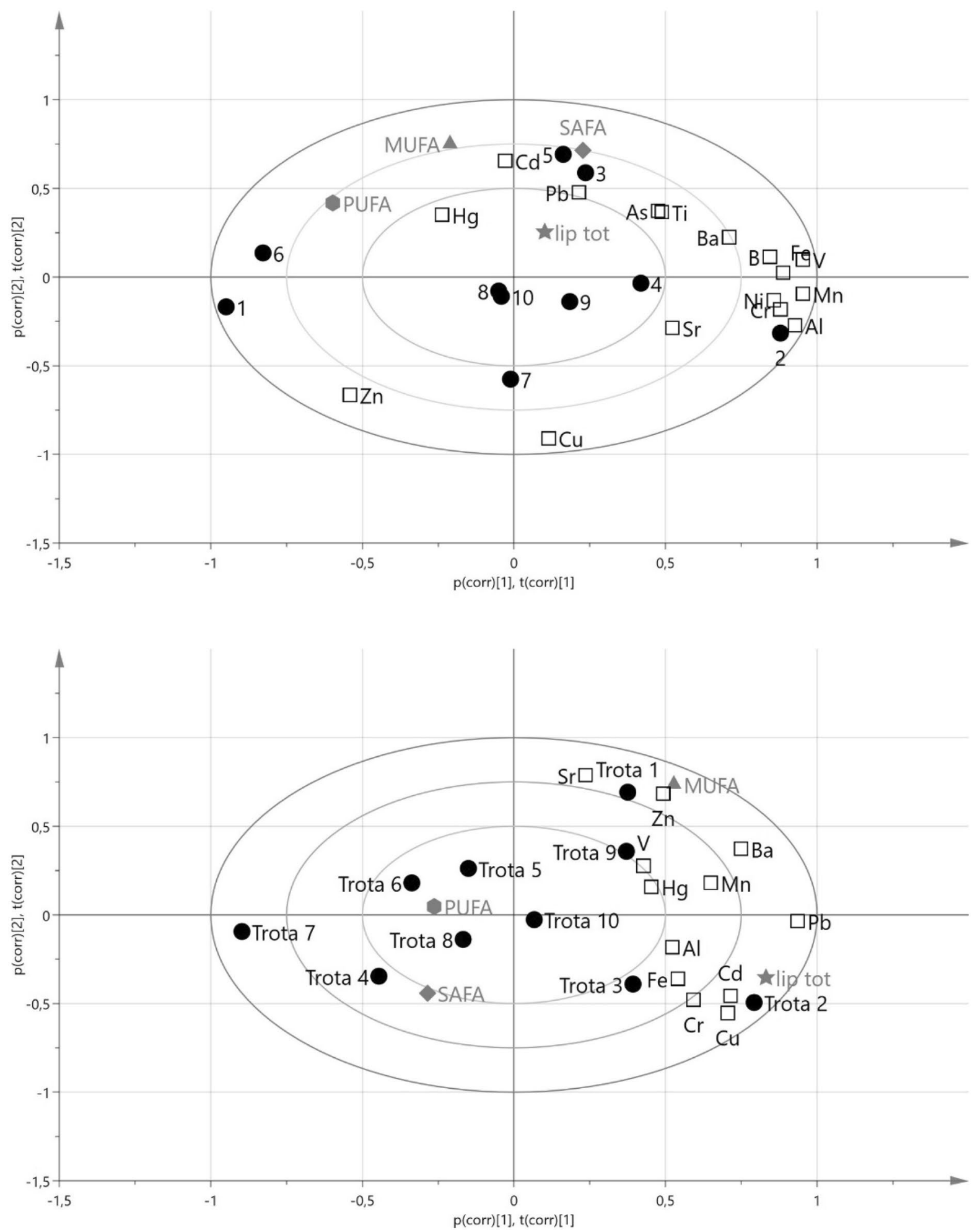

Fig. 3 The PCA biplot loadings. a Correlation of PUFAs to heavy metal accumulation in the gut. b Influence of SAFA and PUFA in metal accumulation 
$\mathrm{cm})$ was slightly higher than the suggested levels for freshwater streams $(50-500 \mu \mathrm{S} / \mathrm{cm})$ and showed that the water in the ponds belongs to springs that extract minerals from rocks, enriching the mineral content in the water (White, 2010) and probably influencing metal accumulation in trout.

As expected, the levels of the 22 metals and metalloids reported in the present study showed both a different distribution and concentration ratio among the gut and EP. Residue levels were higher in the gut than in the EP for all compounds except for $\mathrm{Sr}$ and $\mathrm{Zn}$. Indeed, gut samples included the liver and other organs that accumulate metallothionein proteins; these proteins are involved in homeostatic regulation and the detoxification process from heavy metals and can react strongly with metals (Wang et al., 2014). Al, $\mathrm{Mn}, \mathrm{Fe}, \mathrm{Cu}$, and $\mathrm{Zn}$ are essential elements because of their important role in biological systems. Mn's absence results in severe skeletal and reproductive aberrations in mammals (Sivaperumal et al., 2007). $\mathrm{Cu}$ is a part of several enzymes and is necessary for haemoglobin's biosynthesis with Fe (WHO, 1989). $\mathrm{Zn}$ is an essential trace metal for preventing retarded growth, loss of taste and hypogonadism, and fertility decrease (Sivaperumal et al., 2007). Cr, Ni, and $\mathrm{V}$ are considered essential metals involved in glucose metabolism $(\mathrm{Cr})$, normal growth and reproduction in animals and humans (Ni), and cell growth and essential components of some enzymes (V) (Ahmed et al., 2016). However, when consumed in high amounts, it can result in severe toxicity (Calabrese et al., 1985; Malik et al., 2010). In contrast, Sr, Ba, B, and Ti's biological functions in organisms are still poorly understood, and they are considered non-essential metals (Carvalho et al., 2005). The most abundant metals in the EP and the gut followed the series $\mathrm{Cu}$ $>\mathrm{Zn}>\mathrm{Ba}>\mathrm{Al}>\mathrm{Sr}>\mathrm{Fe}>\mathrm{Pb}$ and $\mathrm{Fe}>\mathrm{Al}>\mathrm{Hg}>\mathrm{As}$ $>\mathrm{Mn}>\mathrm{Cu}>\mathrm{Ba}>\mathrm{B}>\mathrm{Zn}>\mathrm{Pb}$, respectively. $\mathrm{Cd}, \mathrm{Cr}$, $\mathrm{Hg}, \mathrm{Mn}$, and $\mathrm{V}$ were present only in trace amounts in the $\mathrm{EP}$, whereas $\mathrm{Cd}, \mathrm{Cr}, \mathrm{Ni}$, and $\mathrm{V}$ were detected in the gut.

Metals such as $\mathrm{As}, \mathrm{Cd}, \mathrm{Pb}$, and $\mathrm{Hg}$ do not play any metabolic function. In contrast, these metals are considered toxic elements and harmful for humans, even at low concentrations, when ingested over a long period (Tchounwou et al., 2012). According to the European Commission, the allowed limits for $\mathrm{Cd}, \mathrm{Pb}$, and $\mathrm{Hg}$ in fish for human consumption are 0.05, 0.3, and $0.5 \mu \mathrm{g} \mathrm{g}^{-1}$, respectively (EC 1881/2006, 2020;
EC 629/2008, 2020). In this study, the EP samples always showed values lower than the EU Regulation limits. In contrast, considering the gut, $\mathrm{Hg}$ and $\mathrm{Pb}$ showed values 24 times and 2.3 times higher than their MRLs, respectively.

Among the metals and metalloids found in trout samples, only thirteen were investigated by other authors. $\mathrm{Cd}, \mathrm{Cu}, \mathrm{Pb}, \mathrm{Hg}$, and $\mathrm{Zn}$ were the most studied in brown trout, while only a few papers investigated the amounts of $\mathrm{As}, \mathrm{Ba}, \mathrm{Co}, \mathrm{Cr}, \mathrm{Fe}, \mathrm{Mn}, \mathrm{Ni}$, and $\mathrm{V}$. Analysis was carried out on the muscles and the liver, showing values higher in the liver than in the muscles for most compounds (Table 6). The Cd content ranged from 0.02 to $0.04 \mu \mathrm{g} \mathrm{g}^{-1}$ in this study, in both the EP and gut, with average values similar to those found by Dvorak et al. (2016) in brown trout in the Czech Republic but markedly lower than those found in other surveys (Table 6). The average levels of $\mathrm{Cu}$ were similar to those found by Linde et al. (2004) and Monna et al. (2011) but lower than those found by Vitek et al. (2007) in muscles. Moreover, the $\mathrm{Cu}$ levels found in the gut were markedly lower than those detected by other authors in the liver (Table 6).

In contrast, $\mathrm{Hg}$ gut levels were much higher than those found in the liver in other studies (Table 6). $\mathrm{Pb}$ showed variable values among the different studies available, while $\mathrm{Zn}$ was consistently lower in our study. $\mathrm{Cr}$ and $\mathrm{Ni}$ showed similar values to those found by Vitek et al. (2007). Arsenic was studied in rainbow trout (Varol et al., 2017; Robinson et al., 1995), showing a similar concentration to that in our study, while in carp (Jiang et al., 2014), much higher levels were detected. The comparison of literature data with those found in this study clearly showed that metals' accumulation is fish dependent and site-dependent. However, it is uncommon to find high levels of As and $\mathrm{Hg}$ in fish from unpolluted areas, such as in this study. We can tentatively explain this situation considering the geomorphology of the studied site, which showed a derivation from a volcanic eruption that could have led to the release of many metals such as arsenic and mercury (Ma et al., 2019; Witt et al., 2008).

PCA analysis highlighted a different relation between fats and metals' accumulation. Total lipids in the gut were the most connected with $\mathrm{Cd}, \mathrm{Hg}$, and $\mathrm{Pb}$ accumulation, with SAFA fraction the closest among fatty acids. Likewise, EP total lipid loadings were influenced by $\mathrm{Cd}$ and $\mathrm{Pb}$, with MUFA showing a sufficient correlation with $\mathrm{Hg}$ and $\mathrm{Pb}$ amounts. A significant 


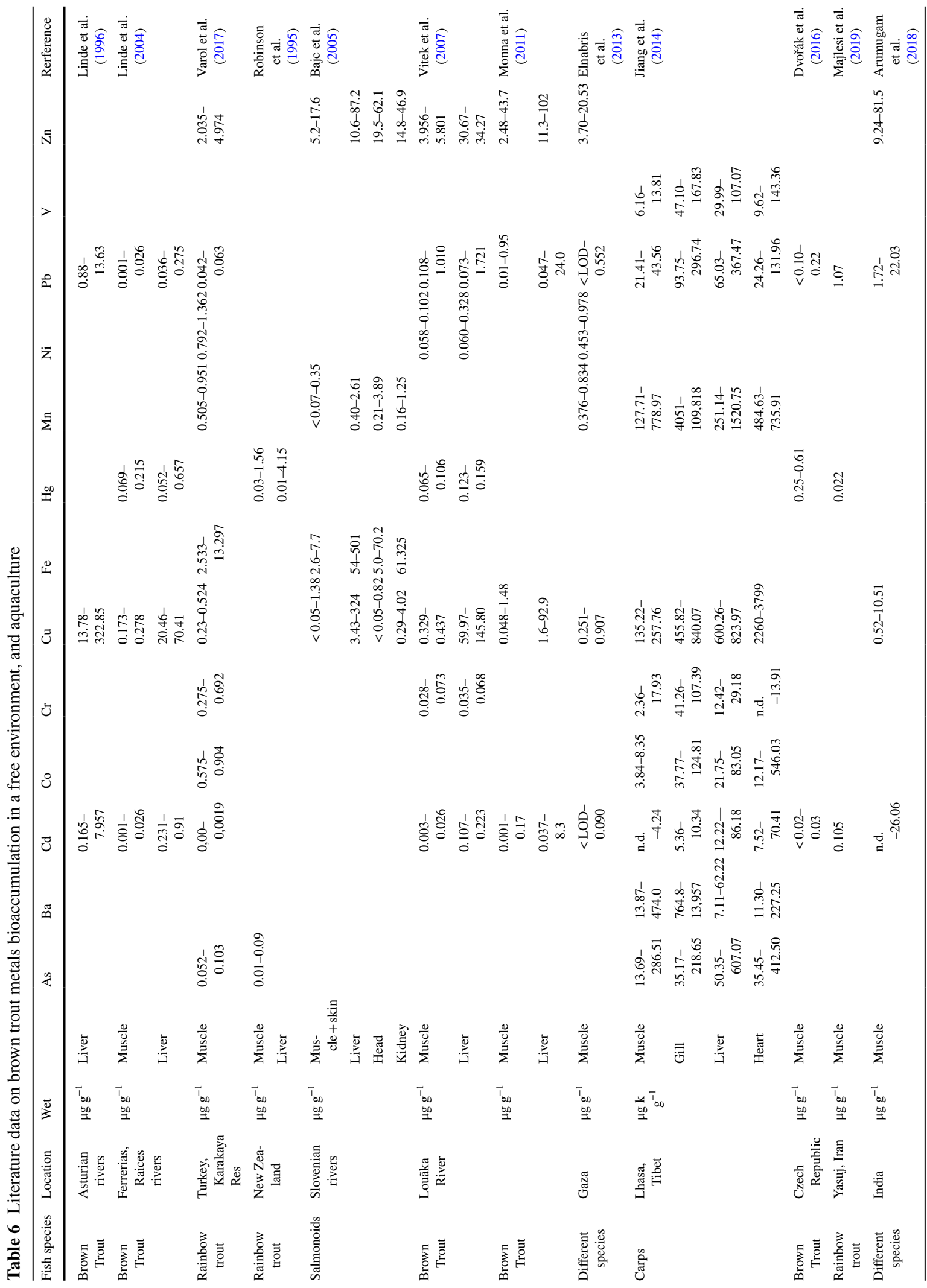


number of papers studied the effect of heavy metals on the amount of protein and lipids in fish muscles; only a few data were reported on the correlation between fatty acid of total lipid content and metals accumulation. Khoshnoud et al. (2011) reported a study on two fish species of the Persian Gulf, recording a negative correlation with PUFA\% for $\mathrm{Pb}(-0.507)$. Moreover, Rajeshkumar and Li (2018) reported the correlation between metals' accumulation and the tissue not differentiating among lipids. They found a high correlation among $\mathrm{Cd}, \mathrm{Pb}$, and internal organs such as the liver.

The THQ values calculated for individual metals showed no harmful values for human health, considering a conventional portion of approximately $0.036 \mathrm{~kg}$ / day EP for a person weighing $67 \mathrm{~kg}$. Thus, the calculated daily intake was below that of the respective reference dose, and these metal levels would not cause any deleterious effect during an entire lifetime. However, some people eat the entire fish (EP+gut), discarding only the head (with the gills) and the backbone; therefore, we calculated the THQ values for the entire fish $(\mathrm{EP}+\mathrm{gut})$. In this case, the values for As and $\mathrm{Hg}$ largely exceeded 1 (Table 5). Severe contamination of the gut draws attention to possible health risks and should be avoided. The EP's total THQ was below 1 (0.49), showing no harmful human health values considering all metals and metalloids in the fish.

Arsenic, cadmium, and lead have been classified by the International Agency for Research on Cancer (2012) as both carcinogenic and non-carcinogenic. Considering whole fish consumption, the TR values for As were more significant than $1 \times 10^{-5}$ (Table 5), suggesting a significant cancer risk due to ingestion of As could exist. Although the carcinogenic effects of As exposure are not yet clear, it has been proposed that the As-mediated intracellular biosynthesis of reactive oxygen species, such as free radicals, may be involved in the carcinogenic process induced via DNA damage. Cancer risk was also possible through Cd exposure since its TR values ranged from $10^{-5}$ in both cases (Table 5). Finally, no risk related to $\mathrm{Pb}$ ingestion seemed possible since its TR value was $4.06 \times 10^{-6}$ in the gut and $9.13 \times 10^{-7}$ in the EP.

\section{Conclusions}

The present investigation confirmed that trout bioaccumulate metals at different rates in the gut and muscles. Moreover, the data obtained confirmed that 
freshwater, even if far from industrial and anthropogenic activities, can lead to the accumulation of heavy metals related to the site's geochemical morphology.

Trout fish were collected from an area originating from a volcanic eruption, followed by siliciclastic depositions in the water basin and complex geomorphology, leading to high levels of $\mathrm{Al}, \mathrm{As}, \mathrm{Cu}, \mathrm{Ba}, \mathrm{Fe}$, $\mathrm{Hg}$, and $\mathrm{Mn}$ in the riverbed.

However, THQ values were below the limit, and non-carcinogenic risk to humans was not associated with the consumption of the EP of brown trout from the selected freshwater site. When fish are consumed with the gut, adverse effects cannot be excluded due to the high levels of As and $\mathrm{Hg}$ accumulated in the gut.

The estimated target cancer risk calculated for As, $\mathrm{Cd}$, and $\mathrm{Pb}$ showed no risk if only the EP was consumed, but attention should be given to the levels of As and $\mathrm{Cd}$ when consuming the entire fish.

If high, harmful metal concentrations are detected, the amounts of fish consumed should be reconsidered.

Author contribution Alberto Angioni: conceptualization, methodology, writing-reviewing and editing. Francesco Corrias: chemical analysis, writing. Alessandro Atzei, Carla Lai: sample preparation and chemical analysis. Andrea Sabatini, Francesco Palmas: identifying and collecting species, writing. Mariateresa Russo: writing-reviewing, and editing.

Funding Open access funding provided by Università degli Studi di Cagliari within the CRUI-CARE Agreement.

Data availability All data generated or analyzed during this study are included in this published article (and its supplementary information files). Moreover, the raw datasets generated during and/or analysed during the current study are available from the corresponding author on reasonable request.

\section{Declarations}

Competing interest The authors declare no competing interests.

Open Access This article is licensed under a Creative Commons Attribution 4.0 International License, which permits use, sharing, adaptation, distribution and reproduction in any medium or format, as long as you give appropriate credit to the original author(s) and the source, provide a link to the Creative Commons licence, and indicate if changes were made. The images or other third party material in this article are included in the article's Creative Commons licence, unless indicated otherwise in a credit line to the material. If material is not included in the article's Creative Commons licence and your intended use is not permitted by statutory regulation or exceeds the permitted use, you will need to obtain permission directly from the copyright holder. To view a copy of this licence, visit http://creativecommons.org/licenses/by/4.0/.

\section{References}

Ahmed, K., Baki, M. A., Kundu, G. K., Islam, S., Islam, M., \& Hossain, M. (2016). Human health risks from heavy metals in fish of Buriganga river. Bangladesh. Springerplus, 5(1697), 1-12. https://doi.org/10.1186/ s40064-016-3357-0

Angioni, A., \& Addis, P. (2014). Characterization of the lipid fraction of wild sea urchin from the Sardinian Sea (Western Mediterranean). Journal of Food Science, 79(2), 155162. https://doi.org/10.1111/1750-3841.12330

Andronico, D., Spinetti, C., Cristaldi, A., \& Buongiorno, M. F. (2009). Observations of Mt. Etna volcanic ash plumes in 2006: An integrated approach from ground-based and polar satellite NOAA-AVHRR monitoring system. Journal of Volcanology and Geothermal Research, 180, 135147. https://doi.org/10.1016/j.jvolgeores.2008.11.013

Arumugam, G., Rajendran, R., Shanmugam, V., Sethu, R., \& Krishnamurthi, M. (2018). Flow of toxic metals in foodweb components of tropical mangrove ecosystem, Southern India. Human and Ecological Risk Assessment: An International Journal, 24(5), 1367-1387. https://doi.org/ 10.1080/10807039.2017.1412819

Atherton, H. J., Bailey, N. J., Zhang, W., Taylor, J., Major, H., Shockcor, J., Clarke, K., \& Griffin, J. L. (2006). A combined 1H NMR spectroscopy and mass spectrometrybased metabolomic study of the PPAR- $\alpha$ null mutant mouse defines profound systemic changes in metabolism linked to the metabolic syndrome. Physiological Genomics, 27, 178-186. https://doi.org/10.1152/physiolgenomics. 00060.2006

Aziz, N. A., Azlan, A., Ismail, A., Alina, S. M., \& Razman, M. R. (2013). Quantitative determination of fatty acids in marine fish and shellfish from warm water of Straits of Malacca for Nutraceutical Purposes. BioMed Research International, 2013, 1-12. https://doi.org/10.1155/2013/ 284329

Beach, L. M., (2010). Determination of As, Sb and Se in difficult environmental samples by hydride generation. Agilent Application Note. Retrieved September 20, 2020, from https://www.agilent.com/cs/library/applications/aa105.pdf

Bajc, Z., Gačnik, K. S., Jenčič, V., \& Doganoc, D. Z. (2005). The contents of $\mathrm{Cu}, \mathrm{Zn}, \mathrm{Fe}$ and $\mathrm{Mn}$ in Slovenian freshwater fish. Slovenian Veterinary Research, 42(1/2), 15-21. UDC 614.31:615.9:543.06:639.3

Bell, M. V., \& Dick, J. R. (2004). Changes in capacity to synthesize 22:6n-3 during early development in rainbow trout (Oncorhynchus mykiss). Aquaculture, 235(1/4), 393-409. https://doi.org/10.1016/j.aquaculture.2003.09.007

Bernatchez, L., Guyomard, R., \& Bonhomme, F. (1992). DNA sequence variation of the mitochondrial control region among geographically and morphologically remote European brown trout Salmo trutta populations. Molecular Ecology, 1(3), 161-173. https://doi.org/10.1111/j.1365294X.1992.tb00172.x 
Berrebi, P., Caputo Barrucchi, V., Splendiani, A., Muracciole, S., Sabatini, A., Palmas, F., Tougard, C., Arculeo, M., \& Marić, S. (2019). Brown trout (Salmo trutta L.) high genetic diversity around Tyrrhenian Sea as revealed by nuclear and mitochondrial markers. Hydrobiologia 826(43), 209-231. https://doi.org/10.1007/s10750-018-3734-5

Buat-Menard, P., \& Arnold, M. (1978). The heavy metal chemistry of atmospheric particulate matter emitted by Mount Etna volcano. Geophysical Research Letters, 5, 245-248. https://doi.org/10.1029/GL005i004p00245

Calabrese, E. J., Canada, A. T., \& Sacco, C. (1985). Trace Elements and Public Health. Annual Review of Public Health, 6(1), 131-146.

Carvalho, M. L., Santiago, S., \& Nunes, M. L. (2005). Assessment of the essential element and heavy metal content of edible fish muscle. Analytical and Bioanalytical Chemistry, 382, 426-432. https://doi.org/10.1007/ s00216-004-3005-3

Charette, M. A., \& Sholkovitz, E. R. (2006). Trace element cycling in a subterranean estuary: Part 2. Geochemistry of the pore water. Geochimica et Cosmochimica Acta, 70(4), 811-826. https://doi.org/10.1016/j.gca.2005.10.019

Corrias, F., Atzei, A., Giglioli, A., Pasquini V., Cau A., Addis, P., Sarais G., \& Angioni A. (2020a). Influence of the technological process on the biochemical composition of fresh Roe and Bottarga from Liza ramada and Mugil cephalus. Foods, 9(10), 1408 1-16. 10.3390/foods9101408.

Corrias, F., Atzei, A., Addis, P., Secci, M., Russo, M. T., \& Angioni, A. (2020b). Integrated environmental evaluation of heavy metals and metalloids bioaccumulation in invertebrates and seaweeds from different marine coastal areas of Sardinia Mediterranean Sea. Environmental Pollution, 266(2), 115048. https://doi.org/10.1016/j.envpol.2020.115048

Costamagna, L. G. (2019). The carbonates of the post-Variscan basins of Sardinia: The evolution from Carboniferous-Permian humid-persistent to Permian arid ephemeral lakes in a morphotectonic framework. Geological Magazine, 156(11), 1892-1914. https://doi.org/10.1017/S001675681 9000232

Cottiglia, M. (1968). La distribuzione dell'ittiofauna dulciacquicola in Sardegna. Rivista di Idrobiologia, 63-116.

Davidson, J., Good, C., Welsh, C., Brazil, B., \& Summerfelt, S. (2009). Heavy metal and waste metabolite accumulation and their potential effect on rainbow trout performance in a replicated water reuse system operated at low or high system flushing rates. Aquacultural Engineering, 41(2), 136-145. https://doi.org/10.1016/j.aquaeng.2009.04.001

Dvořák, P., Andreji, J., Mráz, J., Dvořáková-Líšková, Z., \& Klufová, R. (2016). Ecological risk assessment of heavy metals in brown trout (Salmo trutta m. fario) from the military training area Boletice (Czech Republic). Neuroendocrinology Letters, 37(1), 33-37. ISSN: 0172-780X; ISSN-L: 0172-780X

Elnabris, K. J., Muzyed, S. K., \& El-Ashgar, N. M. (2013). Heavy metal concentrations in some commercially important fishes and their contribution to heavy metals exposure in Palestinian people of Gaza Strip (Palestine). Journal of the Association of Arab Universities for Basic and Applied Sciences, 13(1), 44-51. https://doi.org/10.1016/j.jaubas. 2012.06.001
EC. (2020). Commission Regulation No 1881/2006 of December 192006 setting maximum levels for certain contaminants in foodstuffs. Retrieved September 20, 2020, from https://eurlex.europa.eu/legal-content/EN/TXT/PDF/?uri=CELEX: $32006 \mathrm{R} 1881 \&$ from $=\mathrm{EN}$

EC. (2020). Commission Regulation No 629/2008 of July 2 2008 amending Regulation (EC) No 1881/2006 setting maximum levels for certain contaminants in foodstuffs. Retrieved March 22, 2020, from https://eur-lex.europa.eu/ legal-content/EN/TXT/PDF/?uri=CELEX:32008R0629

EUMOFA. (2020). The Eu Fish Market. 2019 Ed. European Market Observatory for Fisheries and Acquaculture products. Retrieved March 22, 2020, from https://www. eumofa.eu/documents/20178/314856/EN_The+EU+fish+ market_2019.pdf/

EURL - European Union Reference laboratories Official methods for the determination of heavy metals in feed and food. (2012). Heavy metal feed and food. Retrieved March 22, 2020, from https://ec.europa.eu/jrc/sites/jrcsh/files/Official\% 20methods\%20for\%20the \%20determination $\% 20$ of $\% 20$ heavy $\%$ 20metals\%20in\%20feed\%20and\%20food_v4.pdf

Evans, S. J., Johnson, M. S., \& Leah, R. T. (2010). Determination of mercury in fish tissue, a rapid, automated technique for routine analysis. Agilent Application Note. Retrieved March 222020 from https://www.agilent.com/cs/library/applications/AA060. pdf

FAO. (2020) Natural Food and feeding habits. Retrieved March 22, 2020, from http://www.fao.org/fishery/affris/speciesprofiles/rainbow-trout/natural-food-and-feeding-habits/en/

Favalli, M., Mazzarini, F., Pareschi, M. T., Boschi E. (2004). Role of local wind circulation in plume monitoring at Mt. Etna volcano (Sicily) insight from a mesoscale numerical model. Geophysical Research Letter, 31, L09105 1-4. https://doi.org/10.1029/2003GL019281

Fochetti, R., Amici, I., \& Argano, R. (2003). Seasonal changes and selectivity in the diet of brown trout in the River Nera (Central Italy). Journal of Freshwater Ecology, 18(3), 437-444. https://doi.org/10.1080/02705060.2003.9663979

Fontaneto, D., Tommaseo-Ponzetta, M., Galli, C., Risé, P., Glew, R. H., \& Paoletti, M. G. (2011). Differences in fatty acid composition between aquatic and terrestrial insects used as food in human nutrition. Ecology of Food and Nutrition, 50(4), 351-367. https://doi.org/10.1080/03670244.2011. 586316

Gaur, V. K., Sharma, P., Sirohi, R., Awasthi, M. K., Dussap, C. G., \& Pandey, A. (2020). Assessing the impact of industrial waste on environment and mitigation strategies: A comprehensive review. Journal of Hazardous Materials, 398, 123019. https://doi.org/10.1016/j.jhazmat.2020.123019

Garcia-Esquinas, E., Ortola, R., Banegas, J. R., Lopez-Garcia, E., \& Rodriguez-Artalejo, F. (2019). Dietary n-3 polyunsaturated fatty acids, fish intake and healthy ageing. International Journal of Epidemiology, 48(6), 1914-1924. https://doi.org/10.1093/ije/dyz196

Gündoğdu, A., \& Erdem, M. S. (2008). The accumulation of the heavy metals (copper and zinc) in the tissues of rainbow trout (Onchorhyncus mykiss, Walbaum, 1792). Journal of Fisheries Sciences, 2(1), 41-50. https://doi.org/10. 3153/jfscom.2008004

Harris, W. S., Miller, M., Tighe, A. P., Davidson, M. H., \& Schaefer, E. J. (2008). Omega-3 fatty acids and coronary 
heart disease risk: Clinical and mechanistic perspectives. Atherosclerosis, 197(1), 12-24. https://doi.org/10.1016/j. atherosclerosis.2007.11.008

IARC International Agency for Research on Cancer. (2012). Monographs on the evaluation of carcinogenic risks to humans, No. 100C, Lyon, France. Retrieve March 22, 2020, from https://www.ncbi.nlm.nih.gov/books/NBK304375/

IRIS, Integrate Rosk Information System. (2020). Retrieved March 22, 2020, from https://www.epa.gov/iris

Jiang, D., Hu, Z., Liu, F., Zhang, R., Duo, B., Fu, J., Cui, Y., \& Li, M. (2014). Heavy metals levels in fish from aquaculture farms and risk assessment in Lhasa. Tibetan Autonomous Region of China. Ecotoxicology, 23(4), 577-583. https://doi.org/10.1007/s10646-014-1229-3

Jakimska, A., Konieczka, P., Skóra, K., \& Namieśnik, J. (2011). Bioaccumulation of metals in tissues of marine animals, Part I: The role and impact of heavy metals on organisms. Polish Journal of Environmental Studies, 20(5), 1117-1125.

Kiyashko, S. I., Imbs, A. B., Narita, T., Svetashev, V. I., \& Wada, E. (2004). Fatty acid composition of aquatic insect larvae Stictochironomus pictulus (Diptera: Chironomidae): Evidence of feeding upon methanotrophic bacteria. Comparative Biochemistry and Physiology Part $b$ : Biochemistry and Molecular Biology, 139(4), 705-711. https://doi.org/10.1016/j.cbpc.2004.08.013

Khoshnoud, M. J., Mobini, K., Javidnia, K., Hosseinkhezri, P., \& Jamshid, K. A. (2011). Heavy metals ( $\mathrm{Zn}, \mathrm{Cu}, \mathrm{Pb}$, $\mathrm{Cd}$ and $\mathrm{Hg}$ ) contents and fatty acids ratios in two fish species (Scomberomorus commerson and Otolithes ruber) of the Persian Gulf. Iranian Journal of Pharmaceutical Sciences, 7(3), 191-196.

Lee, J. H., O'Keefe, J. H., Lavie, C. J., Marchioli, R., \& Harris, W. S. (2008). Omega-3 fatty acids for cardioprotection. Mayo Clinic Proceedings, 83(3), 324-332. https://doi.org/ 10.4065/83.3.324

Linde, A. R., Arribas, P., Sanchez-Galan, S., \& GarciaVazquez, E. (1996). Eel (Anguilla anguilla) and brown trout (Salmo trutta) target species to assess the biological impact of trace metal pollution in freshwater ecosystems. Archives of Environmental Contamination and Toxicology, 31, 297-302. https://doi.org/10.1007/BF00212668

Linde, A. R., Sanchez-Galan, S., Vallés-Mota, P., \& GarcíaVázquez, E. (2001). Metallothionein as bioindicator of freshwater metal pollution: European eel and brown trout. Ecotoxicology and Environmental Safety, 49(1), 60-63. https://doi.org/10.1006/eesa.2001.2042

Linde, A. R., Sanchez-Galan, S., \& Garcia-Vazquez, E. (2004). Heavy metal contamination of European eel (Anguilla anguilla) and brown trout (Salmo trutta) caught in wild ecosystems in Spain. Journal of Food Protection, 67(10), 2332-2336. https://doi.org/10.4315/0362-028X-67.10.2332

Majlesi, M., Malekzadeh, J., Berizi, E., \& Toori, M. A. (2019). Heavy metal content in farmed rainbow trout in relation to aquaculture area and feed pellets. Foods and Raw Materials, 7(2), 329-338. https://doi.org/10.21603/ 2308-4057-2019-2-329-338

Ma, Q., Han, L., Zhang, J., Zhang, Y., Lang, Q., Li, F., Han, A., Bao, Y., Li, K., \& Alu, S. (2019). Environmental risk assessment of metals in the volcanic soil of Changbai Mountain. International Journal of Environmental
Research and Public Health, 16(11), 2047. https://doi.org/ 10.3390/ijerph16112047

Malik, N., Biswas, A. K., Qureshi, T. A., Borana, K., \& Virha, R. (2010). Bioaccumulation of heavy metals in fish tissues of a freshwater lake of Bhopal. Environmental Monitoring and Assessment, 160(1-4), 267-276. https://doi.org/10. 1007/s10661-008-0693-8

Masindi, V., \& Muedi, K. L. (2018). Environmental contamination by heavy metals. In M. Hosam El-Din, H. E. M. Saleh, \& R. F. Aglan, (Eds). Heavy Metals. (pp 115-133). IntechOpen. https://doi.org/10.5772/intechopen.76082. Retrieve March 22 2020, from https://www.intechopen.com/books/ heavy-metals/environmental-contamination-by-heavy-metals

Massidda, P., Cau, A., Conti, G., \& Loddo, G. (2008). Pesci d'acqua dolce della Sardegna. Aìsara (Ed.). ISBN: 9788861040267

Mohanty, S. B. P., Ganguly, S., Mahanty, A., Mitra, T., Patra, S., Karunakaran, D., Mathew, S., Chakraborty, K., Paul, B.N., Sarma, D., Dayal, S., Singh, S., \& Ayyappan, S. (2019). Fish in human health and nutrition. In B.P. Mohanty (Ed). Advances in fish research Vol. VII (1st ed., Chap 11, pp.189-218). Narendra Publishing House, Delhi.

Monna, F., Camizuli, E., Revelli, P., Biville, C., Thomas, C., Losno, R., Scheifler, R., Bruguier, O., Baron, S., Chateau, C., Ploquin, A., \& Alibert, P. (2011). Wild brown trout affected by historical mining in the Cévennes National Park. France. Environmental Science and Technology, 45(16), 6823-6830. https://doi.org/10.1021/es200755n

NIST/EPA/NIH. (2017). Mass Spectral Library (NIST 17) and NIST Mass Spectral Search Program (Version 2.3).

Oz, M. (2016). Nutrition and gender effect on body composition of rainbow trout (Oncorhynchus mykiss). Reviews in Acquaculture, 1(1), 20-25.

Oz, M. (2019). Effects of habitats and feeding patterns on fatty acid profile of rainbow trout (Oncorhynchus mykiss). Eurasian Journal of Food Science and Technology, 3(2), 34-39.

Palmas, F., Podda, C., Frau, G., Serra, M., Musu, A., Cani, M.V., \& Sabatini, A. (2017). Brown trout distribution updating in Sardinia: A GIS approach for the identification of special conservation zones (SCZ). Atti Second Joint Meeting of Société Zoologique de France and Unione Zoologica Italiana, Congress 2017 de la Société Zoologique de France - 78' Congress dell' Unione Zoologica Italiana, Turin, 19-23 September 2017.

Pastorino, P., \& Prearo, M. (2015). Salmonoids: Systematic, breeding and diseases. First part-Ranibow trout (Onchorhyncus mykiss, Walbaum, 1792). Ittiopatologia, 12, 47-49.

Pasha, H. (2016). Effect of heavy metals on rainbow trout causing potential risk to consumers. Research and Reviews Journal of Zoological Sciences. Special Issue-S2, 121-125.

Petrović, Z., Teodorović, V., Dimitrijević, M., Borozan, S., Beuković, M., \& Milićević, D. (2013). Environmental $\mathrm{Cd}$ and $\mathrm{Zn}$ concentrations in liver and kidney of European hare from different Serbian regions: Age and tissue differences. Bulletin of Environment Contamination and Toxicology, 90(2), 203-207. https://doi.org/10.1007/ s00128-012-0901-7 
Psota, T. L., Gebauer, S. K., \& Kris-Etherton, P. (2006). Dietary omega-3 fatty acid intake and cardiovascular risk. American Journal of Cardiology, 98(4A), 3i-18i. https:// doi.org/10.1016/j.amjcard.2005.12.022

Ptashynski, M. D., Pedlar, R. M., Evans, R. E., Baron, C. L., \& Klaverkamp, J. F. (2002). Toxicology of dietary nickel in lake whitefish (Coregonus clupeaformis). Aquatic Toxicology, 58(3-4), 229-247. https://doi.org/10.1016/s0166$445 \mathrm{x}(01) 00239-9$

Rajeshkumar, S., \& Li, X. (2018). Bioaccumulation of heavy metals in fish species from the Meiliang Bay, Taihu Lake, China. Toxicology Reports, 5, 288-295.

Robinson, B. H., Brooks, R. R., Outred, H. A., \& Kirkman, J. H. (1995). Mercury and arsenic in trout from the Taupo Volcanic Zone and Waikato river, North Island, New Zealand. Chemical Speciation and Bioavability, 7(1). https:// doi.org/10.1080/09542299.1995.11083237

Rounds, S. A., Wilde, F. D., \& Ritz, G. F. (2013). Dissolved oxygen (ver. 3.0): U.S. Geological Survey Techniques of Water-Resources Investigations, book 9, chap. A6, sec. 6.2, https://doi.org/10.3133/twri09A6.2. , http://water.usgs.gov/ owq/FieldManual/Chapter6/6.2_v3.0.pdf

Sabatini, A., Orrù, F., Cannas, R., Serra, P., \& Cau, A. (2006). Conservation and management of Salmo (trutta) macrostigma in Sardinian freshwaters: First result of genetic characterization. Journal of Freshwater Biology, 34, 335-340.

Sabatini, A., Cannas, R., Follesa, M.C., Palmas, F., Manunza, A., Matta, G., Pendugiu, A.A., Serra, P., \& Cau, A. (2011). Genetic characterization and artificial reproduction attempt of endemic Sardinian trout Salmo trutta L., 1758 (Osteichthyes, Salmonidae): Experiences in captivity. Italian Journal of Zoology, 78(1), 20-26. https://doi. org/10.1080/11250003.2010.497171

Sabatini, A., Podda, C., Frau, G., Cani, M. V., Musu, A., Serra, M., \& Palmas, F. (2018). Restoration of native Mediterranean brown trout Salmo cettii Rafinesque, 1810 (Actinopterygii: Salmonidae) populations using an electric barrier as a mitigation tool. The European Zoological Journal, 85(1), 137-149. https://doi.org/10.1080/24750263.2018. 1453554

Sivaperumal, P., Sankar, T. V., \& Nair, V. (2007). Heavy metal concentrations in fish, shellfish and fish products from internal markets of India visà-vis International Standards. Food Chemistry, 102(3), 612-620. https:// doi.org/10.1016/j.foodchem.2006.05.041

Shipley, M. M., Wellington, K., Rao, A., Ritchie, T., \& Vogtsberger, R. C. (2012). Fatty acid composition of a burrowing mayfly, Hexagenia limbata (Ephemeroptera: Ephemeridae), from a North Central Texas Lake. Journal of the Kansas Entomological Society, 85(3), 245258. https://doi.org/10.2317/JKES120831.1

Splendiani, A., Palmas, F., Sabatini, A., \& Caputo Barucchi, V. (2019). The name of the trout: considerations on the taxonomic status of the Salmo trutta L., 1758 complex (Osteichthyes: Salmonidae) in Italy. The European Zoological Journal, 86(1), 432-442. https://doi.org/10.1080/ 24750263.2019.1686544

Tchounwou, P. B., Yedjou, C. G., Patlolla, A. K., \& Sutton, D. J. (2012). Heavy metals toxicity and the environment. In: A. Luch (Ed) Molecular, clinical and environmental toxicology. Experientia Supplementum, vol 101. (pp 133-164). Springer, Basel. https://doi.org/10.1007/ 978-3-7643-8340-4_6

Trbović, D., Vranić, D., Djinovic-Stojanović, J., MatekaloSverak, V., Djordjević, V., Spirić, D., Babić, J., Petronijević, R., \& Spirić, A. (2012). Fatty acid profile in rainbow trout (Oncorhynchus mykiss) as influenced by diet. Biotechnology in Animal Husbandry, 28(3), 563-573. https://doi.org/10.2298/BAH1203563T

Varol, M., Kaya, G. K., \& Alp, A. (2017). Heavy metal and arsenic concentrations in rainbow trout (Oncorhynchus mykiss) farmed in a dam reservoir on the Firat (Euphrates) River: Risk-based consumption advisories. Science of the Total Environment, 599-600, 1288-1296. https:// doi.org/10.1016/j.scitotenv.2017.05.052

Vitek, T., Spurn, P., Mare, J., \& Zikova, A. (2007). Heavy metal contamination of the Louãka River Water Ecosystem. Acta Veterinaria Brno, 76, 149-154. https://doi. org/10.2754/avb200776010149

USEPA. (1989). Risk assessment guidance for superfund: Human health evaluation manual (Part A). (Interim Final, December). Retrieve March 22, 2020, from https://www.epa.gov/sites/production/files/2015-09/ documents/rags_a.pdf

USEPA. (2000). Guidelines for assessing chemical contaminant data for use in fish advisories V.I: Fish sampling and analysis 3rd Ed Office of Science and Technology, Office of Water. Retrieve March 22, 2020, from https:// www.epa.gov/sites/production/files/2015-06/documents/ volume1.pdf

USEPA. (2010). Risk assessment guidance for superfund volume I. Human health evaluation manual (Part A). I. Retrieve March 22 2020, from https://www.epa.gov/ risk/regional-screeninglevels-rsls

Wang, C., Xiong, B., \& Huang, J. (2017a). The role of omega-3 polyunsaturated fatty acids in heart failure: A meta-analysis of randomised controlled trials. Nutrients, 9(1), 18. https://doi.org/10.3390/nu9010018

Wang, Y. J. L., Qu, Z., Wang, C., \& Yang, Z. (2017b). Effects on heavy metal accumulation in freshwater fish: Species, tissues, and sizes. Environmental Science and Pollution, 24, 9379-9386. https://doi.org/10.1007/ s11356-017-8606-4

Wang, W. C., Mao, H., Ma, D. D., \& Yang, W. X. (2014). Characteristics, functions, and applications, of metalloprotein in aquatic vertebrates. Frontiers in Marine Science, 1(34), 1-12. https://doi.org/10.3389/fmars.2014.00034

Wenzl, T., Haedrich, J., Schaechtele, A., Robouch, P., \& Stroka, P. (2016). Guidance document on the estimation of LOD and $L O Q$ for measurements in the field of contaminants in feed and food. EUR 28099 978-92-79-61768-3, Publications Office of the European Union, Luxembourg (2016), https://doi.org/10. 2787/8931. Retrieve March 22, 2020, from https://ec.europa.eu/ jrc/en/publication/guidance-document-estimation-lod-and-loqmeasurements-field-contaminants-feed-and-food

White, W. B. (2010). Springwater geochemistry. In N. Kresic, \& Z. Stevanovic (Eds). Groundwater hydrology of springs engineering, theory, management, and sustainability. (pp 231-268). https://doi.org/10.1016/B978-185617-502-9.00006-2 
WHO. (1989). Environmental Health Criteria 108: Nickel. International Programme on Chemical Safety, World Health Organization. Retrieve 22 March 2020 from www. inchem.org/documents/ehc

WHO. (2007). $\mathrm{pH}$ in drinking water: Revised background document for development of WHO guidelines for drinking water quality. Retrieve March 22 2020, from who. int/water_sanitation_health/dwq/chemicals/ph_revised_ 2007_clean_version.pdf

WHO. (2020). Drinking water guidelines (4th Edition). Chemical fact sheets. Arsenic. World Health Organization, Geneva. Retrieve March 22, 2020, from https://apps.who.int/ iris/bitstream/handle/10665/44584/9789241548151_eng. pdf;jsessionid=828A3425546D9C051C336CAE30E8F2F5? sequence $=1$
Witt, M. L. I., Mather, T. A., Pyle, D. L., Aiuppa, A., Bagnato, E., \& Tsanev, V. I. (2008). Mercury and halogen emissions from Masaya and Telica volcanoes. Nicaragua. Journal of Geophysical Research, 113(b6), B06203. https://doi.org/ 10.1029/2007JB005401

WOAH, World Organization of Animal Health. (2019). Welfare aspects of stunning and killing of farmed fish for human consumption. Retrieved September 20, 2020, from https://www.oie.int/en/standard-setting/aquatic-code/ access-online/

Publisher's Note Springer Nature remains neutral with regard to jurisdictional claims in published maps and institutional affiliations. 